Research, part of a Special Feature on Compensation and Reward for Environmental Services in the Tropics

\title{
Principles for Fairness and Efficiency in Enhancing Environmental Services in Asia: Payments, Compensation, or Co-Investment?
}

\author{
$\underline{\text { Meine van Noordwijk }}^{1}$ and Beria Leimona ${ }^{1,2}$
}

\begin{abstract}
The term payments for environmental services (PES) has rapidly gained popularity, with its focus on market-based mechanisms for enhancing environmental services (ES). Current use of the term, however, covers a broad spectrum of interactions between ES suppliers and beneficiaries. A broader class of mechanisms pursues ES enhancement through compensation or rewards. Such mechanisms can be analyzed on the basis of how they meet four conditions: realistic, conditional, voluntary, and pro-poor. Based on our action research in Asia in the Rewarding Upland Poor for Environmental Services (RUPES) program since 2002, we examine three paradigms: commoditized ES (CES), compensation for opportunities skipped (COS), and co-investment in (environmental) stewardship (CIS). Among the RUPES action research sites, there are several examples of CIS with a focus on assets (natural + human + social capital) that can be expected to provide future flows of ES. CES, equivalent to a strict definition of PES, may represent an abstraction rather than a current reality. COS is a challenge when the legality of opportunities to reduce ES is contested. The primary difference between CES, COS, and CIS is the way in which conditionality is achieved, with additional variation in the scale (individual, household, or community) at which the voluntary principle takes shape. CIS approaches have the greatest opportunity to be pro-poor, as both CES and COS presuppose property rights that the rural poor often do not have. CIS requires and reinforces trust building after initial conflicts over the consequences of resource use on ES have been clarified and a realistic joint appraisal is obtained. CIS will often be part of a multiscale approach to the regeneration and survival of natural capital, alongside respect and appreciation for the guardians and stewards of landscapes.
\end{abstract}

Key Words: Asia; boundary organizations; criteria and indicators; livelihood; payment for environmental services; RUPES

\section{INTRODUCTION}

Payment for environmental services (PES) is widely seen as a way to "financially internalize externalities" and provide land managers with appropriate incentives to opt for land use practices that maintain or enhance the level of environmental services (ES) ${ }^{[1]}$ that are expected, but have not so far been appreciated, by "downstream" or ES beneficiaries (Asquith and Wunder 2008, Porras et al. 2008). In the case of watershed services, the term "downstream" can be taken literally. However, where biodiversity conservation, landscape beauty, or a reduction in net emissions of greenhouse gases is involved, the term is used as a metaphor. There are many current and emerging mechanisms that use the PES terminology, ranging from subsidies for forest owners paid from levies on water or hydropower users, through trade in certificates of rights to pollute (based on certified emission reduction elsewhere), ecotourism and moral incentives to plant trees, to outcome-based contracts to reduce sediment loads of streams and rivers. Although all these mechanisms differ from a command-and-control approach, there is a clear need for more careful descriptors of mechanisms as a basis for comparisons of performance and for reblending of elements to adjust to local context. For a functional taxonomy of mechanisms, we may have to initially cast the net wide and distinguish 
primary and secondary dimensions along which variation occurs. Swallow et al. (2009) proposed the term CRES (compensation and rewards for environmental services) for a broader set of approaches that have enhancement of ES as a common goal. This builds on the combination of environmental science, economic mechanisms, social justice, natural resource management, and public policy perspectives that Tomich et al. (2004) and van Noordwijk et al. (2004a) saw as the conceptual basis for reducing negative externalities of land use decisions in the context of Asian development. As a popular summary, the carrot, stick, and sermons language conveys three approaches to internalization.

Wunder (2005) defined PES as a voluntary transaction in which a well-defined ES is bought by at least one ES buyer from a minimum of one ES provider, if and only if the provider continues to supply that service (conditionality). Strict use of this definition implies that PES does not currently exist in pure form, but partial matches are referred to as "PES-like" (Wunder 2008). There is a wide range of PES-like arrangements, which vary in the type of incentive (payment or use of other currencies), the degree of voluntariness in buyers and sellers, the rights to sell and rights to buy, the degree of negotiation of the transaction, the clarity on what ES is provided, and the way conditionality is made operational. Transforming the social roles to a buyer-seller relationship is not trivial and has consequences for reciprocity.

Although PES has been tested for almost a decade now in developing countries, questions still remain about validity of the concept, the language in which it is couched, and the array of mechanisms for its implementation. Emerging practice in balancing fairness and efficiency differs substantively from widely quoted theory emphasizing efficiency alone. Practitioners may need alternative ways to communicate about what they do, and academic researchers may need to refine their framing of research questions at the interface of disciplinary traditions. Based on our direct involvement in an action research mode in evolving practices in Asia under the Rewarding Upland Poor for Environmental Services (RUPES) ${ }^{[2]}$ program, we will examine the paradigms encountered. We start with distinguishing two main axes (fairness and efficiency) and a tentative set of principles and criteria for realistic, conditional, voluntary, and/or pro-poor enhancement of ES within CRES (Swallow et al. 2009). Three paradigms of ES enhancement differ in some key properties and may between them capture most of the current variation in approaches. We then describe the lessons learned in RUPES and compare practice with the three paradigms, which may provide a better alternative to current PES and PESlike labels for the range of approaches that is currently evolving.

\section{BUILDING BLOCKS FOR THIS REVIEW}

\section{Principles of efficiency and fairness}

The Wunder (2005) definition suggests three key attributes - realistic, conditional, and voluntaryand many ways to (partially) achieve these. Van Noordwijk et al. (2007b) defined three principles with associated criteria and indicators that refer to these properties. They all relate to efficiency, defined as effectiveness at minimized levels of input. This forms the first group of axes for a comparison. A second group can be tentatively labeled "fairness" and requires further analysis.

Before changes of behavior occur in choice and implementation of land use practices that influence ES, a number of conditions must be met: alternatives must be known and understood in their various consequences. In addition to that, complex willingness and motivation need to shift. The motivation combines monetary and cooperative aspects, linked to the social construction of identity. PES suggests that buyer and seller identities can emerge that benefit both sides. The economic paradigm that monetary incentives shift behavior is a partial truth, however, dependent on an "all other things being equal" assumption.

Behavioral economics (Ariely 2008) explores how monetary markets and their efficiency concept interact with fairness concepts that refer to social exchanges, image, and identity (Akerlof and Shiller 2009). If monetary incentives in PES conflict with perceived fairness or aspirations of identity, results may be counter to what was expected. Fairness as used here, matching actual exchanges to accepted social roles, is a broader concept than the quantitatively measurable property of "equity" (Pascual et al. 2010). 
The close interactions between rural livelihoods and ES alongside accepted social roles of agents of developmental change have stimulated interest in pro-poor forms of CRES (Swallow et al. 2009), for both moral and pragmatic reasons. Poverty reduction is the inspirational core of the Millennium Development Goals. If PES mechanisms are not at least neutral on existing inequity, public support may rapidly erode. Disenfranchised rural poor may negatively affect the delivery of environmental services (Scott 1985). The emerging practice of including the perspectives and livelihood strategies of rural poor has tended to avoid marginalization of non-PES participants (Grieg-Gran et al. 2005, Pagiola et al. 2005, Leimona et al. 2009), even though the generation of PES is linked to land and land ownership is not in the hands of the poor. We thus include pro-poor here as a fourth principle, representing the fairness cluster, and broadly define poverty as a condition lacking at least one of the assets (capitals) of the sustainable livelihood approach (Chambers and Conway 1992).

\section{Stocks (assets) versus flows}

The five capitals (stocks) considered in the livelihood analysis are human, social, natural, physical (infrastructure), and monetary capital; each has a flow (harvest, depletion, change, and investment) equivalent. PES connects a financial flow ("payment") to a flow of services. Conventional flow-based definitions of poverty (less than US\$ X per person per day) can be compared with poverty concepts based on critical lack of assets. Similarly, shortfalls in ES flows and/ or lack of investment in their restoration are linked to the level of natural capital operating at different time scales (van Noordwijk et al. 2004a). An alternative to the PES framing may be a focus on "investment in natural capital" as a basis for future ES (Wackernagel and Rees 1997).

\section{Principles, criteria, and indicators}

For the four principles recognized within efficiency and fairness clusters (i.e., realistic, voluntary, conditional, and pro-poor), van Noordwijk et al. (2007b) suggested criteria that may require contextspecific operational indicators.
Realistic: tangible and sustainable reduction or avoidance of human-induced threats to ES flows and associated stocks (and/or measurable recovery from past decline of ES) at relevant spatial and temporal scale, relative to a nonintervention ("business-as-usual") baseline.

Early signs that buyers get uneasy with a lack of service delivery in PES schemes (Kleijn et al. 2001, Landell-Mills and Porras 2001) have not had major consequences in the dominant PES literature, but the gap between perceptions and measurable indicators is receiving attention. Although the popular perception in many parts of Asia (and the world) is that only forests can provide the watershed functions required for effective use of hydropower and/or extraction of drinking water, science does not support such propositions. Many examples exist of watersheds with mosaics of forest patches, agroforestry zones, and paddy rice fields that provide a regular flow of water of low-sediment load, depending on the rainfall regime. Watershed functions do not justify special treatment for forest per se, and user payments for watershed services may need to be allocated beyond the forest management entities (Calder 2001, van Noordwijk et al. 2001, Agus et al. 2004, van Noordwijk et al. 2007a, Bruijnzeel and van Noordwijk 2008). A recent turn in the global debate on forests and floods supports a focus on the actual infiltration capacity of soils rather than on forest as a land use category (van Dijk et al. 2009, Malmer et al. 2010).

Compared with quantifiable watershed services, there is considerably less scope for providing full biodiversity conservation functions along with any extraction of goods or forms of agroforestry (Schroth et al. 2004). The matrix of landscape mosaics surrounding protected areas does matter, however, for the biodiversity that can be conserved in the landscape as a whole (Michon et al. 2007, Scherr and McNeeley 2007, Pfund et al. 2008). Recent meta-analyses have confirmed a positive role for ecological corridors (Gilbert-Norton et al. 2010), further challenging the concept of "indicator species" as proxies (Cushman et al. 2010). The current prominence of a utilitarian "ecosystem services" portrayal is increasingly questioned (Peterson et al. 2010), with more intrinsic ecosystem functioning as alternative concept. A proposal (Wiens and Bachelet 2010) to focus on the diversity of arenas rather than current actors in the face of 
climate change adaptation aligns with a need for investment in ecological infrastructure, rather than protecting current flagship species. In practice, however, conservation funding decisions do not match these concepts as yet.

In the debate on global incentives for reducing emissions from deforestation and forest degradation (REDD), the issue of "realistic" depends on the negotiated reference scenario for national-scale emissions, the specific cut-off point of the forest definition used, and the local opportunities for high carbon-stock sustainable development (Swallow et al. 2007b, 2009).

Voluntary: engagement of both ES providers and beneficiaries in a negotiated scheme through free and informed choice at the individual level.

Acting voluntarily contrasts with the providers being the object of enforced restrictions, such as government regulations toward their decisions to land practices (even if the latter implies a right to compensation). A perceived threat of external regulation, however, may induce "voluntary" selfregulation. A weaker form of voluntary decision making refers to agreements at the scale of collective action for providers as often found in customary societies and/or beneficiaries; this is common when electricity or water monopolists include a levy.

Voluntary mechanisms require "free and prior informed consent (FPIC)" (Colchester 2004) as a basis for agreements, where both sides (ES providers and beneficiaries) can judge whether or not there is a balance between their rights and obligations. The informed part of this refers back to the assessment of realistic, but there is a challenge in the efficiency of delegation (not everybody has to be at every meeting) versus the risks of elite capture and self-declared representativeness on behalf of key stakeholders. Meeting the standards for voluntary thus requires considerable effort in social mobilization (Leimona et al. 2008a).

The domain for voluntary enhancement of ES that can qualify for rewards or payments is the complement of the mandatory protection of such services through land use restrictions in sensitive areas and rules against pollution of air, water, or soil (Swallow et al. 2009). In many Asian countries, the regulation is ahead of compliance in many environmental laws; thus, there is a need for national policy dialogues (Leimona et al. 2008b) to revise legal frameworks.

Conditional: benefits received by ES providers depend on performance measures agreed in contracts between parties, with conditions known and understood by all relevant stakeholders.

A key element to distinguish PES and CRES from taxes and subsidies is the degree to which there is a performance basis of conditionality for the rewards/ payments rather than an entitlement based on nominal entities such as forest, without specifying the actual services delivered by different forest types in different landscape and climatic conditions. We can distinguish conditionality at the level of input (Did people spend the time on planting trees or guarding the forest?), the condition of the system (Are the trees growing? Is the forest still intact?), or the actual outcomes for ES (clean water throughout the year). Therefore, different levels of conditionality exist between local agents (i.e., ES providers and their associated intermediaries) and external agents (i.e., ES beneficiaries and their associated intermediaries). ES contracts link tangible benefits for the ES providers to the actual enhanced delivery of ES (level I), and/or maintenance of agroecosystems in a desirable state (level II), and/or performance of agreed actions to enhance ES (level III), and/or development and implementation of management plans to enhance ES or respect for local sovereignty in managing the environment for local plus external benefits (level IV) (Fig. 1).

Shifting from "inputs" to "condition of the system" implies respect for local managers in their ability to fine-tune decisions on input use, but makes it more difficult to calculate the minimum value of conservation contact. This calls for more subtle negotiations and also for clear rules for monitoring and evaluation. It creates opportunities for net benefits to emerge at local level, beyond compensation for direct costs of implementation. Conditionality can be used for financial payments (as in most market-based delivery contracts for goods) but also for land tenure in sensitive watershed areas (Suyanto et al. 2008), with maintenance of healthy watersheds as a condition for the continuation of land use rights. 
Fig. 1. Four levels of conditionality between local agents (ES providers and associated intermediaries) and external agents (ES beneficiaries and associated intermediaries) (modified from van Noordwijk et al. 2004b)

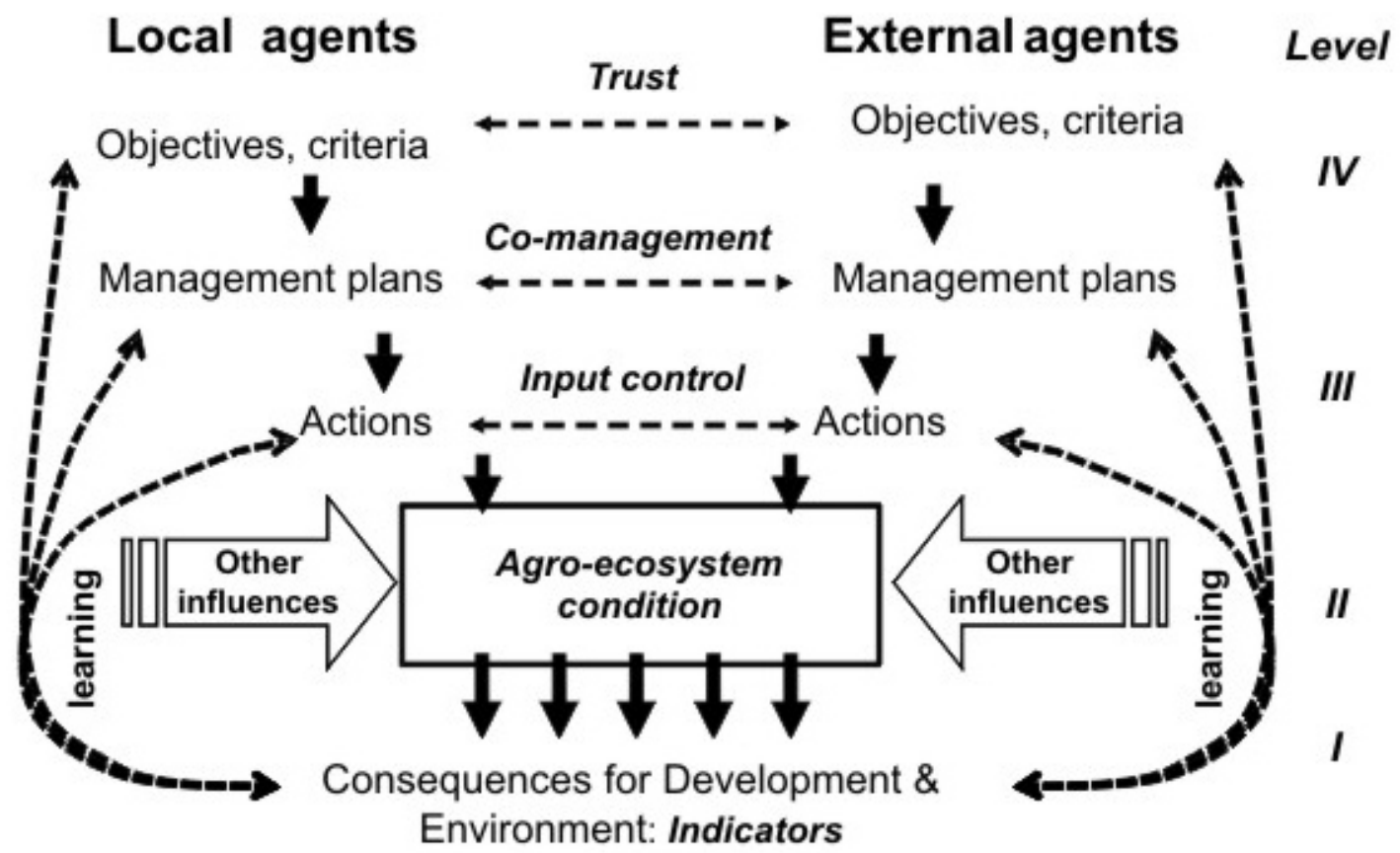

These three principles (realistic, voluntary, and conditional) refer to effectiveness, when measured for impact on ES, and efficiency, when effectiveness is expressed per unit investment by ES beneficiaries. A fourth principle, pro-poor, refers to fairness.

Pro-poor: access, process, decision making, and outcomes of the schemes are differentiated by wealth or gender among ES providers and beneficiaries, and support a positive bias toward poor stakeholders in either group to comply with the Millennium Development Goals and as a step toward long-term sustainability.

Rural poverty is increased by environmental degradation but may also contribute to its cause. ES issues cannot be sustainably secured without reduction in poverty, but if payments focus on landowners, they may increase local inequity. The type of reward may need to be based on the local determinants of poverty and address key local concerns.
Leimona et al. (2009) analyzed the potential for PES to have a significant effect on poverty reduction in the uplands of Asia. In terms of cash flow, the potential is limited if expressed on a per capita basis, as the potential number of beneficiaries is large. The potential total value of financial transfers in enhancing ES can be expressed relative to the current income of poor ES providers. Given a total value, either a small group can benefit substantially or a large group marginally, but policy-relevant outcomes on rural poverty alleviation can only be expected if a large group can benefit at a daily income level that helps in meeting the US\$1 per person per day threshold (or its national poverty line equivalent). Leimona et al. (2009) expressed the per capita benefits in terms of a number of dimensionless ratios of upstream and downstream: area, population density, income, willingness to pay by downstream beneficiaries, transaction costs, and the offset fraction of the opportunity costs of alternative land uses that might generate more income, but provide fewer ES. Using available statistics for Indonesia, an across-the-board target 
of a $5 \%$ increase in disposable income in the uplands is only feasible in specific contexts, where area and population ratios differ from the average and/or if the downstream population is willing and able to pay at least $4 \%$ of their income as a contribution to $\mathrm{ES}$ provision in the upstream area.

\section{Action research at sites and national level}

The RUPES Phase I has been in operation since 2002 and has developed a set of six action research ${ }^{[3]}$ sites in Indonesia, the Philippines, and Nepal ${ }^{[4]}$ to build working models of rewards for ES schemes adapted to the Asian context. Targeted action research is identifying the ES and how they can be measured. It is looking at whom the rewards should go to, who will pay the rewards, how and in what form they would be collected, and what amount or form is appropriate. We are analyzing how innovative institutional arrangements and reward mechanisms can be applied to foster local development and environmental conservation.

These questions, in essence, were the basis for the exploration of the realistic, voluntary, conditional, and pro-poor principles as elaborated in the conceptual basis of the program (Tomich et al. 2004, van Noordwijk et al. 2004a). The four principles as currently recognized (Swallow et al. 2007a, van Noordwijk et al. 2008a,b) became a major vehicle for synthesizing the main lessons learned from the action research mode, where researchers and project staff reflected together with local project partners on what had been achieved. An overview of the RUPES and learning sites is provided in Table 1, with characterization of the main ES issue, the type of conditionality, and the mechanism under development.

Throughout the implementation of the RUPES project, the distinction between rewards (which can come in any currency derived from any of the five livelihood capitals: natural, financial, human, social, and physical) and payments (which are expected to be in monetary terms) was a recurrent topic of debate. On further reflection, three paradigms were identified in this debate: commoditized environmental services (CES), compensation for opportunity skipped (COS), and co-investment in stewardship (CIS).

\section{CES/COS/CIS paradigms for compensation and rewards to enhance ES}

Communities living in the landscape and managing (de facto if not always de jure) parts of its resources produce both marketable goods and environmental services (Fig. 2) through their access to the five livelihood capitals. Each of these capitals increases or decreases flow processes. In addition, the community can derive income from the temporary export of labor as another way of using its resources.

In a landscape, the community deals with three other main groups in five major ways (see arrows in Fig. 2):

1. Private sector entities who buy marketable commodities for further processing and trade and/or use the landscape resources for added value (e.g., through hydropower or the sale of drinking water)

2. Governments imposing rules on the private sector and their interaction with ES

3. Government agencies, sometimes acting to represent international conventions, regulating what the community is allowed to do, how it has to organize its administration, and how it can be part of development processes prioritized at higher levels

4. Consumers who buy local goods and may be interested in supporting ES as well

5. Consumers elsewhere in the world who opt for competitively priced goods but also have concerns about the status of poverty indicators, natural resources, and human rights in the area

The government as regulators can use three methods (loosely identified as carrots, sticks, and sermons) to influence local resource management: financial incentives (e.g., tax reduction), spatially explicit regulation of resource access and procedures for their enforcement (e.g., putting fences surrounding protected area), and moral persuasion. The regulators obtain their income primarily from the private sector, and their political power comes from votes from the local community. In the latter instance, a balancing act arises that can be quite distinct (and distant) from the concerns of the external consumers. 


\section{Table 1. Site level experience in the RUPES Phase I project in Asia}

\begin{tabular}{lll}
\hline \hline Site Focus of environmental service & $\begin{array}{l}\text { Conditionality applied } \\
\text { (see Fig. 1) }\end{array}$ & Type of scheme and current status \\
\hline
\end{tabular}

\section{Indonesia}

Bungo

"Jungle rubber" agroforestry system Level IV for conservation of the diversity of local plant species and wildlife habitat

Management plan for rubber agroforestry in general, including specified agricultural techniques No slash-and-burn practices Minimizing illegal logging at the buffer zone of the adjacent national park and traditional community forests "lubuk larangan"

No intensive or commercial harvesting of nontimber forest products or hunting

Cidanau

Water quality and regular flow for private water companies

Singkarak

(Watershed)

Water quality for hydropower, native fish conservation, and ecotourism

Level II

Planting and maintaining timber and fruit trees with the total minimum of 500 trees $^{-1}$ for 5 years

Level IV

Planting a 40-ha grassland with timber and fruit trees

Singkarak (Voluntary Carbon Market)

Carbon sequestration for voluntary markets under land rehabilitation setting

Sumberjaya

(Community

Forestry)

Watershed rehabilitation for the District Forestry Service

Sumberjaya (River Water quality for hydropower Care)

\section{The Philippines}

Bakun

Water quality for hydropower

Kalahan

Carbon sequestration under voluntary market

Nepal

Kulekhani
Water quality for hydropower

\section{Level I}

Planting and maintaining a specified number of trees to achieve an agreed amount of carbon sequestration

Level II

Planting and maintaining a specified number of trees with a particular composition of species

Level I

Conducting collective action in riparian rehabilitation and sedimentation reduction to achieve a specified percentage (>30\%) of erosion reduction

Level III

Setting up management plan to rehabilitate watershed, including sustainable horticulpractices

Level I

Planting and maintaining a specified number of trees to achieve agreed amount of carbon sequestration
"Hutan desa" ("village forest") recognition by central government for local forest management role within watershed protection forest Testing mini-hydropower as intermediate reward for biodiversity conservation

A private buyer (automotive wheel industry) showing interest in rubber for "green" vehicles

A private water company is paying

US\$120/ha for the contract

Conservation fund from local government to revitalize organic coffee in the upstream watershed

Carbon market negotiated with private buyer (consumer goods distributor)

Conditional tenure rewarded to farmer groups

Hydroelectric power company (HEP) royalty agreements signed for River Care groups along the river
HEP royalty agreements signed

Carbon market initial agreement with private buyer (automotive industry)

Level III Setting up management plan to rehabilitate watershed, including sustainable horticulture practices
HEP royalty agreements signed 
Fig. 2. Relationships between environmental goods and services provision, actors in the landscape, and five assets (capitals): natural (soil, land, and water), human (capacity to manage resources), social (healthy local institutions), physical (adequate access to public infrastructure), and financial (adequate money to invest).

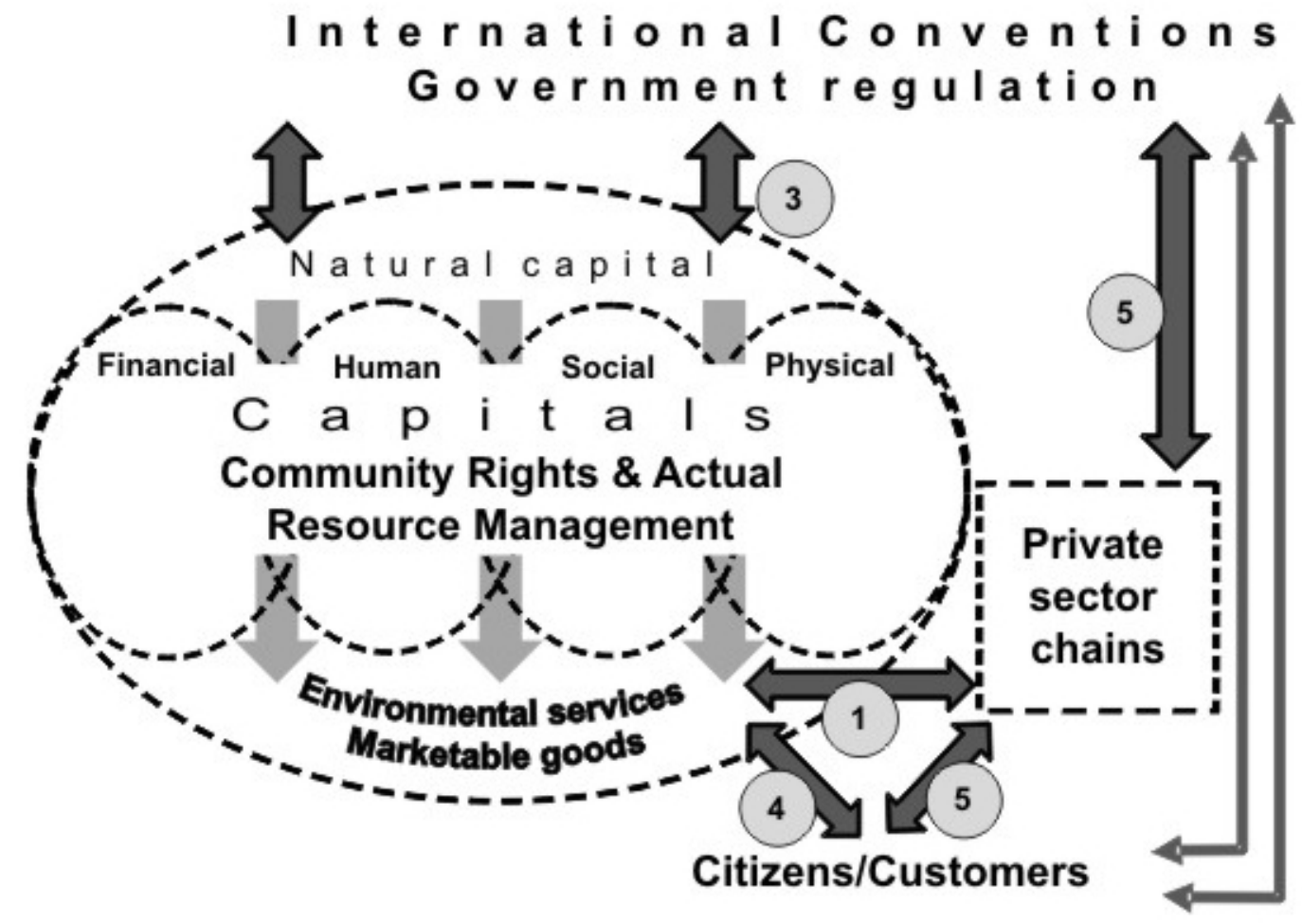

The interactions with the private sector are primarily through the sale of marketable goods but may also involve investments in provision of agricultural inputs, land clearing, and technology, as in outgrower schemes. The private sector transforms local marketable goods and ES (such as a regular supply of clean water) into marketable goods with added value. It prefers to have free access to public ES but will settle for a range of other options to secure continued access to the resources it needs. Options that link financial outlays to greater security and a competitive edge in resource access are preferred. The private sector, however, also needs to produce goods with competitive pricing for its consumers that match their expectations of quality. If the private sector needs to invest in local ES and human welfare, this has to be reflected in the price of goods.

CES, COS, and CIS are three paradigms or ways to organize thinking about, and analysis of, compensation and rewards (including payments) for ES involving various combinations of the actors in Fig. 2. The three paradigms differ in conditionality (Fig. 1) and in primary actor relationships (Fig. 2): arrows 1 and 4 for CES; 2 and 3 for COS; and 1, 3, and 4 (backed up by 2 and 5) in the case of CIS.

\section{Paradigm CES: commoditized environmental services}

Paradigm CES is when ES procurement operates at conditionality level I (Fig. 1) based on actual service delivery and direct marketability. The CES paradigm is focused on direct interaction between the community that provides ES (or the ES providers) and ES beneficiaries (arrows 1 and 4 in Fig 2). The price level for recurrent monetary payments in this paradigm may be fully negotiable (based on supply and demand) and provides new sources of income for those who can control land and the other resources necessary in the production 
of ES. Innovations can be expected in how to costeffectively enhance commoditized ES production. There is no explicit poverty target.

\section{Paradigm COS: compensating for opportunities skipped}

Paradigm COS is paying land users for accepting restrictions (either voluntary or mandatory) on their use of land. COS has conditionality at level II or III (Fig. 1). The basis of contracts depends on the achievement of an objectively measurable condition of the (agro)-ecosystem or the expended level of effort (or restrictions in input use). The COS paradigm focuses on relations between government on one hand (on behalf of its citizens) and the private sector and local community on the other (arrows 2 and 3 in Fig. 2). This paradigm may involve recurrent monetary payments based on restrictions imposed by local or national government and/or voluntarily accepted on privately owned land with the possibility of collective action. The basis of financial compensation in this paradigm is the opportunity costs of foregoing economically attractive and legally permissible land use patterns that reduce ES. Poverty reduction targets can be added through differentiation in pay when prices are externally set rather than freely negotiated.

\section{Paradigm CIS: co-investment in (landscape) stewardship}

Paradigm CIS is focused on assets and generally aspiring conditionality at level IV (Fig. 1), with levels II or III in transitional forms. It combines arrow 3 in Fig. 2 with arrows 4 and 1 (in response to arrows 5 and 2). Relative to a collectively owned or state-owned land and natural resource base, it can include the following: (1) negotiated tenure, conditional on ES maintenance; (2) reduction of land use conflicts and their collateral damage to ES; (3) investment in improved public services, feeder roads under community control, and (4) land use and development planning that creates employment that does not damage ES. The conditionality level IV (entrust the local resource management) is when the buyers have full trust that the management plan (including local monitoring) set up by the community will enhance the provision of ES with a flexible contract, broad sanctions, and a monitoring requirement. CIS explicitly adds social capital to the mix.

\section{RESULTS}

\section{Linking principles, sites, and paradigms in RUPES sites}

Table 2 summarizes the links between different paradigms and principles in enhancing ES. Within the RUPES experience, the voluntary carbon project in Singkarak, Indonesia (Edi et al. 2010) and Kalahan, the Philippines (Villamor et al. 2010) has come closest to the CES paradigm. It relates land use and ES with certified emission reduction as the proxy for measuring ES. The CES paradigm is currently tested in a watershed context in the "River Care" case study in Sumberjaya (http://rupes.world agroforestry.org/researchsite sumberjaya/6). RUPES and a hydropower company experimented with a performance-based payment for reducing the sediment load in streams based on locally selected actions, after a common diagnostic phase. In practice, however, unraveling the effect of climatic variability and landscape condition on the performance parameter (sediment concentration) proved to be complex (Bruijnzeel and van Noordwijk 2008). ${ }^{[5]}$ As the case evolved, performance below the previously agreed baseline was still accepted by the buyer as due to force majeure. Explicit appreciation by the hydropower company for the efforts made effectively brought in CIS-type social relationship building beyond a market-based CES.

The market-based CES paradigm presupposes individual property rights because, generally, the contractual arrangement strictly clarifies "who provides what and how much." However, our action research sites showed that collective rather than individual household decisions received most attention, with reliance on existing local perceptions of rights and responsibilities, even for the CES paradigm, such as in Singkarak and Sumberjaya (Leimona et al. 2009). Furthermore, monitoring the actual delivery of ES can be problematic with technical difficulties for the community (Leimona et al. 2009).

\section{Linking principles, sites, and paradigms elsewhere}

Reanalysis of popular global PES schemes, such as the Proambiante program in Brazil (Southgate and Wunder 2009), the Pimampiro case in Ecuador (Echavarria et al. 2003, Wunder and Alban 2008), 
Table 2. Experience relevant to three contrasting paradigms across the RUPES sites (listed in Table 1)

\begin{tabular}{|c|c|c|c|}
\hline & Paradigm CES & Paradigm COS & Paradigm CIS \\
\hline $\begin{array}{l}\text { Examples in global } \\
\text { literature }\end{array}$ & $\begin{array}{l}\text { Most of the Voluntary } \\
\text { Carbon Market }\end{array}$ & $\begin{array}{l}\text { Proambiante program, Brazil } \\
\text { Pimampiro, Ecuador } \\
\text { PSA program, Costa Rica } \\
\text { Most of the payment schemes } \\
\text { for (assumed) watershed } \\
\text { functions in Latin America } \\
\text { and Asia }\end{array}$ & $\begin{array}{l}\text { Grain for Green project, China } \\
\text { National PES project, Vietnam } \\
\text { Andes, Bolivia (Asquith et al. } \\
\text { 2008) }\end{array}$ \\
\hline $\begin{array}{l}\text { Example studies in } \\
\text { RUPES } \\
\text { (Table 1) }\end{array}$ & $\begin{array}{l}\text { Sumberjaya (River Care) } \\
\text { Singkarak (Voluntary Carbon } \\
\text { Market) } \\
\text { Kalahan (Voluntary Carbon } \\
\text { Market) }\end{array}$ & Cidanau & $\begin{array}{l}\text { Bungo } \\
\text { Singkarak (Watershed) } \\
\text { Sumberjaya (Community } \\
\text { Forestry) } \\
\text { Bakun } \\
\text { Kulekhani }\end{array}$ \\
\hline \multicolumn{4}{|l|}{$\begin{array}{l}\text { Do schemes meet the } \\
\text { principles? }\end{array}$} \\
\hline Realistic & $\begin{array}{l}\text { Yes, as long as ES is } \\
\text { measurable }\end{array}$ & $\begin{array}{l}\text { Only if correctly targeted; } \\
\text { mostly long-term }\end{array}$ & Mostly long-term \\
\hline Voluntary & $\begin{array}{l}\text { Yes, for those who are in a } \\
\text { position to control and } \\
\text { enhance ES }\end{array}$ & $\begin{array}{l}\text { Yes, for those with rights and } \\
\text { opportunity to reduce ES }\end{array}$ & $\begin{array}{l}\text { Yes, for collective action } \\
\text { scheme, FPIC depending on } \\
\text { local social capital and } \\
\text { decisions }\end{array}$ \\
\hline Conditionality (Fig. 1) & Level I & Levels II-III & Levels I-IV \\
\hline Pro-poor & $\begin{array}{l}\text { Possibly not, presupposes } \\
\text { tenure security }\end{array}$ & $\begin{array}{l}\text { Possibly yes, depending on } \\
\text { allocation rules }\end{array}$ & $\begin{array}{l}\text { Mostly yes, depending on local } \\
\text { institutions }\end{array}$ \\
\hline Primary strength & $\begin{array}{l}\text { The output is based on the } \\
\text { ES provision, ensuring the } \\
\text { effect of the project }\end{array}$ & $\begin{array}{l}\text { Relatively easy to monitor } \\
\text { with tangible indicators at } \\
\text { effort level rather than } \\
\text { outcome level }\end{array}$ & $\begin{array}{l}\text { Trust-building and reciprocity } \\
\text { redress past inequalities }\end{array}$ \\
\hline Primary challenge & $\begin{array}{l}\text { Considerable risk to the ES } \\
\text { providers if their efforts do } \\
\text { not pay off. The monitoring } \\
\text { process requires technical } \\
\text { capacity because of } \\
\text { complexity in measuring ES. }\end{array}$ & $\begin{array}{l}\text { The conditionality might not } \\
\text { directly link with the ES } \\
\text { provision. Buyers have budget } \\
\text { restriction for the financial } \\
\text { payments. }\end{array}$ & $\begin{array}{l}\text { Need high trust between the } \\
\text { seller and buyer. Similar to } \\
\text { COS, the conditionality might } \\
\text { not directly link with ES } \\
\text { provision and financial } \\
\text { opportunity cost might not be } \\
\text { fully paid. }\end{array}$ \\
\hline
\end{tabular}

and Costa Rica's Pagos de Servicios Ambientales (PES) program and related ES payment schemes for (assumed) watershed functions in Latin America (Southgate and Wunder 2009) and Asia (Munawir and Vermeulen 2007, Leimona et al. 2009), shows that these cases fit the COS paradigm. They use the efforts of ES providers (such as planting trees) as the weaker proxy for measuring the ES provisions (such as regular water flow for domestic water users).

Government-driven PES programs, such as the Grain for Green project in China and Vietnam and RUPES cases in Bungo, Bakun, and Kulekhani, 
highlight that where poverty is a major issue, enhancement of ES cannot be disentangled from development needs. The limited capacity of the actors involved and the lack of biophysical data for a full scientific basis for a PES to be implemented are reasons for broader approaches to enhance ES. As discussed above, communities in developing countries depend greatly on social contacts in managing their landscapes. They share customary, inherited values and respect trust and mutual understanding. This norm influences their relationship with ES beneficiaries and other group members of ES providers, and only dealing with people that they trust adds complexity to the scheme. All of these elements indicate that a CES relying on only money transfer between (individual) ES sellers and buyers with strict conditionality generally cannot work in developing countries. However, COS and CIS schemes have risks for not to be propoor when the co-benefit of the scheme cannot exceed both the economic and noneconomic costs of the schemes. The magnitude of total benefits received by each ES provider is dependent on benefit allocation rules among ES providers (Fisher et al. 2010) and robust institutional design (Corbera et al. 2007), especially under a collective action scheme.

\section{DISCUSSION AND CONCLUSION}

A strict interpretation of realistic, conditional, and voluntary PES (paradigm CES or commoditized ES) appeared problematic in most sites and situations. The question "Who deserves to be paid for improving ES?" is not simple in current situations when the lack of clarity on natural resource tenure rights is a major problem in developing countries (Giller et al. 2008). The question "Who deserves pay for not destroying natural capital?" is morally suspect in most contexts. What starts off as an additional incentive may soon be seen as an entitlement. When some get paid and others do not, the results may be interpreted as a potential future threat to ES by those who did not get prime attention. The net effect of PES to the overall level of ES may then decline. This perverse effect is often discussed, and there are some early signs that it may be real in a number of situations. It may be related to the transformation of existing (but underperforming) reciprocity norms to a buyer-seller relation without paying an adequate price. Further analysis of the conceptual failure is needed (Wunder 2006). The "business" language in which PES is often expressed may be partly to blame (Lele et al. 2010, Kosoy and Corbera 2010, Pascual et al. 2010).

Recent experiments on the interface of behavioral economics and psychology support an interpretation that human interactions within a social capital context follow different rationality rather than interactions that directly involve money (Ariely 2008). Experiments showed that people sometimes expend more effort in exchange for no payment (in a social market, expecting reciprocity) than they expend when they receive low payment (a monetary market). Experimental evidence also demonstrates that mixed markets (markets that include aspects of both social and monetary markets) more closely resemble monetary than social markets (Heyman and Ariely 2004). Even subtle reminders of money elicit big changes in human behavior. Relative to participants primed with neutral concepts, participants primed with language about money preferred to play alone, work alone, and put more physical distance between themselves and a new acquaintance (Vohs et al. 2006). On the other hand, reminders of money prompted participants to work harder on challenging tasks and led to desires to take on more work as compared with participants not reminded of money (Vohs et al. 2008). Image motivation, the desire to be liked and well-regarded by others, as a driver in prosocial behavior (doing good) is crowded out by extrinsic monetary incentives (doing well) (Ariely et al. 2009). Monetary incentives may be counterproductive for public pro-social activities, when they undermine existing norms and are not sufficient and/or durable enough to offset this loss of intrinsic motivation. Replacing the "payment" concept with "coinvestment" language is an effort to appeal to both social and financial concepts. Whether or not this can work at a universally human psychological level and/or in a culture-dependent learned set of norms will require further analysis and experimentation.

The interest in long-term assets versus current services varies among the ES and the amount of place-based investment of ES beneficiaries. For example, the economic lifespan of the investment of a hydropower company or drinking water reservoir requires a direct matching with the time over which the ES are needed. A more mobile tanker-level drinking water supplier may have more choices and thus less reason to invest for long time 
periods. Global concerns about biodiversity are focused on slowing the rate of anthropogenic biodiversity loss, with a long-term perspective. So, short-term PES schemes, which postpone local extinctions by a few years, are pointless.

Only a small part of the ES can be "packaged" in quantities that can be traded in open markets, detached from the place of origin of the commodity. Reducing net emissions of greenhouse gases may appear to be the least place-bound, because greenhouse gases have similar effects on the atmosphere wherever they are emitted or sequestered. Therefore, the carbon market is probably the closest approximation to a full commoditization of ES. However, even here, current contractual obligations include aspects of permanence or the complex and low-value "temporary emission reduction credits" that were created for Afforestation/Reforestation of the Clean Development Mechanism (CDM) in the Kyoto Protocol and have found little application (van Noordwijk et al. 2008c).

The comparison of rehabilitation versus avoided degradation or deforestation may illustrate a further point. Rehabilitation may require an initial investment. Avoided degradation or deforestation is a recurrent offsetting of forgone opportunities for more economically beneficial land use that still exists. The institutions for investment in projects that supposedly start a self-sustaining path (such as rehabilitation projects) are more open to private sector engagement than those involving the longterm modification of incentives (such as avoided degradation or deforestation projects). The latter may be difficult without the involvement of public sector institutions. One-off investment for rehabilitation contrasts with recurrent payments for avoided degradation or deforestation. An investment focus on assets contrasts with a payment concept for flows. The simple PES paradigm thus requires revision or enrichment of both arguments: payment versus investment and flows versus stock.

In a PES concept as defined by Wunder (2005), the markets may ultimately become the mechanism to efficiently balance supply and demand for ES, but at this stage, information is restricted, asymmetrical (Ferraro 2008), and incomplete. Brokers are needed to provide access to knowledge and clarify bargaining positions. On the other side of the spectrum, a benevolent top-down governance system that tries to impose fairness in actions to enhance ES as public goods will require detailed knowledge of how ES are affected by the many options and realities in land use. In between these two extreme positions, there is a need for public investment in the development of "boundary objects" or knowledge products that can be accepted by the various stakeholders as a background for their negotiations of adjusting action. Enhancing ES through forms of compensation, rewards, or payments requires linking knowledge and action, and so may benefit from boundary organizations ${ }^{[6]}$ (Cash et al. 2006).

\section{Scale issues}

Within a PES scheme, the financial rewards obtained by voluntary enhancement of ES must at least offset the real opportunity cost of modified land use (and opportunities forgone) after paying the transaction costs. Levels of reward higher than this will provide real benefit, but the benefits may also be thought to derive from local spinoffs through enhanced local ES. In the paradigm of CIS, this cost-benefit approach is considerably broadened. The function of total capital values (i.e., natural, human, social, physical, and financial) supplied to ES providers through various forms of investment and rewards must match their opportunity cost in terms of the functions of all five capitals plus transaction costs. Transaction costs may themselves have a positive aspect of relation-building and external communication that can be valued. This broader approach involves tradeoffs between capital types, as well as tradeoffs between land use practices that vary in their provision of goods and services. It may defy quantitative analysis.

With global concerns over climate change, the global architecture of incentives to reduce emissions from land use and land use change (including forestry) is under debate. The criteria of realistic, voluntary, conditional, and pro-poor apply at the global scale of interactions between countries, as much as they apply at the local scale of CRES. However, there is considerable scope for nested systems that allow countries to exchange greenhouse gas emissions for financial incentives at the national border and use this for an array of local incentives for forms of sustainable development that are compatible with "high carbon stock livelihoods" (Swallow and van Noordwijk 
2008). The existing legal framework for forest management may need to be adjusted so that the conditionality is appropriately regulated (Galudra et al. 2008). At the local level, a number of barriers to farmer tree planting and community-based forest management have been identified, such as lack of land use rights, good planting material, know-how on tree management, and access to markets for tree products (Roshetko et al. 2008, van Noordwijk et al. 2008d). A multiscale approach may use paradigm CES in the relationship between countries, exchanging financial capital for verifiable and agreed emission reduction, while the government uses the funds so obtained (or the loans that can be repaid in such a way) for mechanisms that are following COS or CIS language and logic, providing co-investment in generic ES that happen to have carbon co-benefits, rather than targeting emission reduction as their primary goal.

In summary, our experiences in Asia suggest that PES schemes may need to address a livelihood approach that considers the five capital types (human, social, physical, financial, and natural) in their interactions across scales. The interactions of all livelihood capitals address the preconditions for the CES and COS paradigms and may well have to be the foundation for all such efforts. A language of CIS, "co-investment" and "shared responsibility" may be more conducive to the type of respect, mutual accountability, and commitment to sustainable development that is needed. It retains reference to social exchange rather than financial transactions. Yet, there are opportunities for phased strategies. After creating a basis of respect and relationships through the paradigm of CIS, there may be more space for specific follow-ups in the paradigm of CES for actual delivery of ES to meet conservation objectives. The simple conceptual scheme of buyers, sellers, intermediaries, and regulators that was used in many initial developments of PES schemes may need to be modified to incorporate a more holistic livelihood perspective and the combined efforts through moral persuasion, regulations, and rewards to modify local resource-use decisions in the uplands.

Responses to this article can be read online at: http://www.ecologyandsociety.org/vol15/iss4/art17/ responses/

\section{Acknowledgments:}

The ideas in this paper have gradually matured following discussions with partners, consideration of the results from regional workshops, global overviews, and a synthesis of the Compensation and Rewards for Environmental Services (CRES) Scoping Study tasked by the International Development Research Centre (IDRC). We acknowledge Brent Swallow, Lucy Emerton, Thomas P. Tomich, Sandra J. Velarde, Mikkel Kallesoe, and Madhushree Sekher for their ideas and fruitful input to earlier versions of this paper, and William C. Clark, Elisabeth McNie, Nancy Dickens, and Delia Catacutan for discussions of concepts. The International Fund for Agriculture and Development (IFAD), the European Union, and a National Science Foundation grant, in cooperation with Harvard University ("Boundary Organizations"), co-invested in the research presented here, but these institutions are not responsible for the content.

\section{LITERATURE CITED}

Agus, F., Farida, and M. van Noordwijk, editors. 2004. Hydrological impacts of forest, agroforestry and upland cropping as a basis for rewarding environmental service providers in Indonesia. Proceedings of a workshop in Padang/Singkarak, West Sumatra, Indonesia. 25-28 February 2004. World Agroforestry Centre-ICRAF,SEA Regional Office, Bogor, Indonesia. [online] URL: http://ww w.worldagroforestrycentre.org/sea/Publications/searchpub. asp?publishid=1557.

Akerlof, G. A., and R. J. Shiller. 2009. Animal spirits: how human psychology drives the economy and why it matters for global capitalism. Princeton University Press, Princeton, New Jersey, USA.

Ariely, D. 2008. Predictably irrational: the hidden forces that shape our decisions. Harper, New York, New York, USA.

Ariely D., A. Bracha, and S. Meier. 2009. Doing good or doing well? Image motivation and monetary incentives in behaving prosocially. American Economic Review 99:544-555 
Asquith, N., and S. Wunder, editors. 2008. Payments for watershed services: the Bellagio conversations. Fundación Natura, Santa Cruz de la Sierra, Bolivia.

Bruijnzeel, S., and M. van Noordwijk. 2008. Deforestation and the multiple functions of tropical watersheds: are tropical forests indispensable for regulating rainfall and ensuring clean and reliable water supplies? ASB Policy Brief 08. ASB Partnerships for the Tropical Forest Margins, Nairobi, Kenya. [online] URL: http://www.asb.cgiar. org/pdfwebdocs/PolicyBrief 08 On-Tropical-Forestsand-water.pdf.

Calder, I. 2001. Forest valuation and water: the need to reconcile public and science perceptions. Pages 49-62 in P. Verweij, editor. Understanding and capturing the multiple values of tropical forest. Tropenbos International, Wageningen, Netherlands.

Carpenter, S. R., R. DeFries, T. Dietz, H. A. Mooney, S. Polasky, W. V. Reid, and R. J. Scholes. 2006. Millennium Ecosystem Assessment: research needs. Science 314:257-258.

Cash, D. W., W. N. Adger, F. Berkes, P. Garden, L. Lebel, P. Olsson, L. Pritchard, and O. Young. 2006. Scale and cross-scale dynamics: governance and information in a multilevel world. Ecology and Society 11: 8. [online] http://www.ecologyandsociety. org/vol11/iss2/art8/.

Chambers, R., and G. R. Conway. 1992. Sustainable rural livelihoods: practical concepts for the 21st century. IDS Discussion Paper. Institute of Development Studies, Brighton, UK.

Colchester, M. 2004. Conservation policy and indigenous peoples. Environmental Science \& Policy 7:145-153.

Corbera, E., N. Kosoy, and M. Martínez Tuna. 2007. Equity implications of marketing ecosystem services in protected areas and rural communities: case studies from Meso-America. Global Environmental Change 17:365-380.

Cushman, S. A., K. S. Mckelvey, B. R. Noon, and K. Mcgarigal. 2010. Use of abundance of one species as a surrogate for abundance of others. Conservation Biology 24:830-840.
Echavarria, M., J. Vogel, M. Albán, and F. Meneses. 2003. The impacts of payments for watershed services in Ecuador. Emerging lessons from Pimampiro and Cuenca. International Institute for Environment and Development, London, UK.

Edi, I. M., B. Leimona, R. Pasha, and D. Harja. 2010. A smallholder voluntary carbon scheme: an experience from Nagari Paningahan, West Sumatra, Indonesia. Working Paper 105. World Agroforestry Centre, Nairobi, Kenya, in press.

Ferraro, P. J. 2008. Asymmetric information and contract design for payments for environmental services. Ecological Economics 65:810-821.

Fisher, B., K. Kulindwa, I. Mwanyoka, R. K. Turner, and N. D. Burgess. 2010. Common pool resource management and PES: lessons and constraints for water PES in Tanzania. Ecological Economics 69:1253-1261.

Galudra, G., M. van Noordwijk, B. Leimona, and N. Sakuntaladewi. 2008. The Indonesian forestry laws as basis for a REDD regime? RECOFTC, Bangkok, Thailand [online] URL: http://www.reco ftc.org/site/fileadmin/docs/e-letter-documents/eletter2008/ CF E-News June 2008 web.html.

Gilbert-Norton, L., R. Wilson, J. R. Stevens, and K. H. Beard. 2010. A meta-analytic review of corridor effectiveness. Conservation Biology 24:660-668

Grieg-Gran, M., I. Porras, and S. Wunder. 2005. How can market mechanisms for forest environmental services help the poor? Preliminary lessons from Latin America. World Development 33 (9):1511-1527.

Giller, K. E., C. Leeuwis, J.-A. Andersson, W. Andriesse, A. Brouwer, P. Frost, P. Hebinck, I. Heitkönig, M.-K. van Ittersum, N. Koning, R. Ruben, M. Slingerland, H. Udo, T. Veldkamp, C. van de Vijver, M.-T. van Wijk, and $P$. Windmeijer. 2008. Competing claims on natural resources: what role for science? Ecology and Society 13: 34. [online] URL: http://www.ecologya ndsociety.org/vol13/iss2/art34/.

Heyman, J., and D. Ariely. 2004. Effort for payment, a tale of two markets. Psychological Science 15:787-793. 
Kleijn, D., F. Berendse, R. Smit, and N. Gilissen. 2001. Agri-environment schemes do not effectively protect biodiversity in Dutch agricultural landscapes. Nature 413:723-725.

Kosoy, N., and E. Corbera. 2010. Payments for ecosystem services as commodity fetishism. Ecological Economics 69:1228-1236.

Landell-Mills, N., and I. Porras. 2001. Silver bullet or fools' gold: a global review of markets for forest environmental services and their impact on the poor. International Institute for Environment and Development, London, UK.

Leimona, B., M. van Noordwijk, G. B. Villamor, A. Fauzi, S. Upadhyaya, and Farida. 2008a. Social mobilization and local awareness of rights and opportunities for environmental services market. World Agroforestry Centre-ICRAF, SEA Regional Office, Bogor, Indonesia. [online] URL: http://www.worldagroforestry.org/sea/Publications/ files/leaflet/LE0084-08.PDF.

Leimona, B., M. van Noordwijk, G. B. Villamor, and G. Galudra. 2008b. National policy dialogue on environmental services supply through regulation, voluntary agreements and markets. World Agroforestry Centre-ICRAF, SEA Regional Office, Bogor, Indonesia. [online] URL: http://ww w.worldagroforestry.org/sea/Publications/files/leaflet/ LE0085-08.PDF.

Leimona, B., L. Joshi, and M. van Noordwijk. 2009. Can rewards for environmental services benefit the poor? Lessons from Asia. International Journal of the Commons 3:82-107. [online] URL: http://www.thecommonsjournal.org/index.php/ijc/article/ view/121.

Lele, S., P. Wilshusen, D. Brockington, R. Seidler, and K. Bawa. 2010. Beyond exclusion: alternative approaches to biodiversity conservation in the developing tropics. Current Opinion in Environmental Sustainability 2:94-100.

Malmer, A., D. M. Murdiyarso, L. A. Bruijnzeel, and U. Ingstedt. 2010. Carbon sequestration in tropical forests and water: a critical look at the basis for commonly used generalizations. Global Change Biology 16:599-604.

Michon, G., H. De Foresta, P. Levang, and F.
Verdeaux. 2007. Domestic forests: a new paradigm for integrating local communities' forestry into tropical forest science. Ecology and Society 12: 1. [online] URL: http://www.ecologyandsociety.org/vol12/ iss2/art1/.

Munawir, S., and S. Vermeulen.. 2007 Fair deals for watershed services in Indonesia. International Institute for Environment and Development, London, UK.

Pagiola, S., A. Acenas, and G. Platais. 2005. Can payments for environmental services help reduce poverty? An exploration of the issues and the evidence to date from Latin America. World Development 33(2):237-253.

Pascual, U., R. Muradian, L. C. Rodríguez, and A. Duraiappah. 2010. Exploring the links between equity and efficiency in payments for environmental services: a conceptual approach. Ecological Economics 69:1237-1244.

Peterson, M. J., D. M. Hall, A. M. FeldpauschParker, and T. R. Peterson. 2010. Obscuring ecosystem function with application of the ecosystem services concept. Conservation Biology 24:113-119.

Pfund, J. L., P. Koponen, T. O'Connor, J. M. Boffa, M. van Noordwijk, and J. P. Sorg. 2008. Biodiversity conservation and sustainable livelihoods in tropical forest landscapes. Pages 297-322 in R. Lafortezza, J. Chen, G. Sanesi, and T. R. Crow, editors. Patterns and processes in forest landscapes: multiple use and sustainable management. Springer, Berlin, Germany.

Porras, I., M. Grieg-Gran, and N. Neves. 2008. All that glitters: a review of payments for watershed services in developing countries. International Institute for Environment and Development, London, UK.

Roshetko, J. M., D. J. Snelder, R. D. Lasco, and M. van Noordwijk. 2008. Future challenge: a paradigm shift in the forestry sector. Pages 451-483 in D. J. Snelder and R. D. Lasco, editors. Smallholder tree growing for rural development and environmental services: lessons from Asia. Advances in Agroforestry, Volume 5. Springer, Berlin, Germany.

Scherr, S. J., and J. A. McNeely, editors. 2007. 
Farming with nature: the science and practice of ecoagriculture. Island Press, Washington, D.C., USA.

Scott, J. C. 1985. Weapons of the weak: everyday forms of peasant resistance. Yale University Press, New Haven, Connecticut, USA.

Schroth, G., G. A. B. da Fonseca, C. A. Harvey, C. Gascon, H. L. Vasconcelos, and A. N. Izac, editors. 2004. Agroforestry and biodiversity conservation in tropical landscapes. Agroforestry Systems 68:247-249.

Southgate, D., and S. Wunder. 2009. Paying for watershed services in Latin America: a review of current initiatives. Journal of Sustainable Forestry 28:497-524.

Suyanto, S., B. Leimona, M. van Noordwijk, and G. Galudra. 2008. Conditional tenure as a reward for environmental services. World Agroforestry Centre-ICRAF, SEA Regional Office, Bogor, Indonesia. [online] URL: http://www.worldagrofor estry.org/sea/Publications/files/leaflet/LE0083-08.PDF

Swallow, B., M. Kallesoe, U. Iftikhar, M. van Noordwijk, C. Bracer, S. Scherr, K. V. Raju, S. Poats, A. Duraiappah, B. Ochieng, H. Mallee, and R. Rumley. 2007a. Compensation and rewards for environmental services in the developing world: framing pan-tropical analysis and comparison. Working Paper 32. World Agroforestry Centre, Nairobi, Kenya. [online] URL: http://www.worldag roforestrycentre.org/downloads/publications/PDFs/ WP14963.PDF.

Swallow, B. M., M. van Noordwijk, S. Dewi, D. Murdiyarso, D. White, J. Gockowski, G. Hyman, S. Budidarsono, V. Robiglio, V. Meadu, A. Ekadinata, F. Agus, K. Hairiah, P. Mbile, D. J. Sonwa, and S. Weise. 2007b. Opportunities for avoided deforestation with sustainable benefits: an interim report of the ASB partnership for the tropical forest margins. ASB Partnership for the Tropical Forest Margins, Nairobi, Kenya. [online] URL: http://www.worldagroforestry.org/sea/Publications/ searchpub.asp?publishid=1784.

Swallow, B., and M. van Noordwijk. 2008. Restoring the functions of watersheds: agroforestry systems that are intermediate between natural forests and intensive foodcrop agriculture can restore can restore most if not all watershed functions attributed to natural forests. ASB Policy Briefs 09. ASB Partnerships for the Tropical Forest Margins, Nairobi, Kenya. [online] URL: http://ww w.asb.cgiar.org/publications/view.asp?Pub $\mathrm{ID}=1003$

Swallow, B. M., M. F. Kallesoe, U. A. Iftikhar, M. van Noordwijk, C. Bracer, S. J. Scherr, K. V. Raju, S. V. Poats, A. Kumar Duraiappah, B. O. Ochieng, H. Mallee, and R. Rumley. 2009. Compensation and rewards for environmental services in the developing world: framing pantropical analysis and comparison. Ecology and Society 14: 26. [online] URL: http://www.ecologya ndsociety.org/vol14/iss2/art26/.

Tomich T. P., D. E. Thomas, and M. van Noordwijk. 2004. Environmental services and land use change in Southeast Asia: from recognition to regulation or reward? Agriculture, Ecosystems and Environment 104:229-244.

van Dijk, A. I. J. M., M. van Noordwijk, I. R. Calder, S. L. A. Bruijnzeel, J. Schellekens, and N. A. Chappell. 2009. Forest-flood relation still tenuous - comment on "Global evidence that deforestation amplifies flood risk and severity in the developing world" by C. J. A. Bradshaw, N. S. Sodi, K. S. H. Peh, and B. W. Brook. Global Change Biology 15(1):110-115.

van Noordwijk, M., T. P. Tomich, and B. Verbist. 2001. Negotiation support models for integrated natural resource management in tropical forest margins. Conservation Ecology 5(2):21 [online] URL: http://www.consecol.org/vol5/iss2/art21.

van Noordwijk, M., F. Chandler, and T. P. Tomich. 2004a. An introduction to the conceptual basis of RUPES: rewarding upland poor for the environmental services they provide. ICRAFSoutheast Asia, Bogor, Indonesia.

van Noordwijk, M., J. Poulsen, and P. Ericksen. 2004b. Filters, flows and fallacies: quantifying offsite effects of land use change. Agriculture, Ecosystems and Environment 104:19-34.

van Noordwijk, M., F. Agus, B. Verbist, K. Hairiah, and T. P. Tomich. 2007a. Managing watershed services in ecoagriculture landscapes. 
Pages 191-212 in S. J. Scherr and J. A. McNeely, editors. Farming with nature: the science and practice of ecoagriculture. Island Press, Washington, D.C., USA.

van Noordwijk, M., B. Leimona, L. Emerton, T. P. Tomich, S. Velarde, M. Kallesoe, M. Sekher, and B.Swallow. 2007b. Criteria and indicators for ecosystem service reward and compensation mechanisms: realistic, voluntary, conditional and pro-poor. Working Paper 37. World Agroforestry Centre, Nairobi, Kenya. [online] URL: http://www. worldagroforestry.org/downloads/publications/PDFs/ WP14964.PDF.

van Noordwijk, M., B. Leimona, M. H., Hoang, G. B. Villamor, and T. Yatich. 2008a. Payments for environmental services. ETFRN News 49:95-100.

van Noordwijk M., B. Leimona, G. B. Villamor, and G. Galudra. 2008b. Dealing with mythperceptions: how to reduce communication and perception gaps before Rewards for Environmental Services negotiations can start? World Agroforestry Centre-ICRAF, SEA Regional Office, Bogor, Indonesia. [online] URL: http://www.worldagrofor estry.org/sea/Publications/files/leaflet/LE0082-08.PDF.

van Noordwijk, M., J. M. Roshetko, Murniati, M. D. Angeles, Suyanto, C. Fay, and T. P. Tomich. 2008c. Farmer tree planting barriers to sustainable forest management. Pages 427-449 in D. J. Snelder and R. D. Lasco, editors. Smallholder tree growing for rural development and environmental services: lessons from Asia. Advances in Agroforestry Volume 5. Springer, Berlin, Germany.

van Noordwijk, M., D. A. Suyamto, B. Lusiana, A. Ekadinata, and K. Hairiah. 2008d. Facilitating agroforestation of landscapes for sustainable benefits: tradeoffs between carbon stocks and local development benefits in Indonesia according to the FALLOW model. Agriculture, Ecosystems and Environment 126:98-112.

Villamor, G. B., R. Forcadilla, N. Bugtong, D. Pulan, J. Alanano, and D. Rice. 2010. Rapid Carbon Stock Appraisal (RACSA) in Kalahan, Nueva Vizcaya, Philippines. Working Paper. World Agroforestry Centre, Nairobi, Kenya, in press.
Vohs, K. D., N. L. Mead, and M. R. Goode. 2006. Psychological consequences of money. Science 314:1154-1156.

Vohs, K. D., N. L. Mead, and M. R. Goode. 2008. Merely activating the concept of money changes personal and interpersonal behavior. Current Directions in Psychological Science 17:208-212.

Wackernagel, M., and W. E. Rees. 1997. Perceptual and structural barriers to investing in natural capital. Economics from an ecological footprint perspective. Ecological Economics 20:3-24.

Wiens, J. A., and D. Bachelet. 2010. Matching the multiple scales of conservation with the multiple scales of climate change. Conservation Biology 24:51-62.

Wunder, S. 2005. Payments for environmental services: some nuts and bolts. CIFOR Occasional Paper 42. Center for International Forestry Research, Bogor, Indonesia. [online] URL: http://w ww.cifor.cgiar.org/Knowledge/Publications/Detail? pid=1760.

Wunder, S. 2006. Are direct payments for environmental services spelling doom for sustainable forest management in the tropics? Ecology and Society 11: 23. [online] URL: http://w ww.ecologyandsociety.org/vol11/iss2/art23/.

Wunder, S. 2008. Payments for environmental services and the poor: concepts and preliminary evidence. Environment and Development Economics 13:279-297.

Wunder, S., and M. Albán. 2008. Decentralized payments for environmental services: the cases of Pimampiro and PROFAFOR in Ecuador. Ecological Economics 65:685-698.

[1] The term ecosystem services, according to the Millennium Ecosystem Assessment (Carpenter et al. 2006), includes both "provisioning" services (including all of agriculture and forest industries), which tend to have existing markets for goods, and regulating, supporting, and cultural services that were previously labeled "environmental services"; 
we use the latter term (van Noordwijk et al. 2004a). [2] The RUPES project Phase I was a project coordinated by the World Agroforestry Centre (2002-2007). The goal of the project was to enhance the livelihoods and reduce poverty of the upland poor while supporting environmental conservation through rewards for ES. For further reference, see http://rupes.worldagroforestry.org/.

[3] Action research is a systematic, reflective study of one's actions, and the effects of these actions will be analyzed, shared, and formulated to new plans for action during the next cycle. The Center for Collaborative Action Research defines action research as "a way of learning from and through one's practice by working through a set of reflective stages that helps a person develop a form of 'adaptive' expertise." Source: http://cadres.pepperd ine.edu/ccar/define.html, downloaded on February 17, 2010.

[4] Publications in various forms are accessible through the website. The models, along with the national policy dialogues, were initiated in Indonesia, the Philippines, and Vietnam. An international workshop for practitioners and scientists reviewed and synthesized the results of the RUPES Phase I project.

[5] The paper discusses complex interactions between weather and vegetation and factors influencing the restoration of watershed functions. For example, the intensity of rainfall is the most important factor affecting annual water yield. Human-induced action, such as removal of forest, initially increases annual water yield. Further, people can influence this process by choosing the type of vegetation (such as replacing trees with less "thirsty" plants such as grasses and annual crops that allow groundwater reserves to recover as long as soil degradation is kept moderate) and the degree of soil compaction in subsequent years. An interesting question that is relevant to any ES payment scheme is "Who is the main provider of rainfall (that influences annual water yield)?"

${ }^{[6]}$ Organizations that sit, at least metaphorically, in the territory between science and politics, interfacing or bridging the pursuit of scientific research with policy decision and public actions. 